http://dx.doi.org/10.12775/szhf.2021.021

\author{
OKsana Sheremeta \\ Narodowa Akademia Nauk Ukrainy, Kijów, Ukraina \\ E-MAIL: OSHEREMETA2015@GMAIL.COM \\ ORCID: 0000-0001-8364-4300
}

\title{
Kontekst socjologiczny historyczno-filozoficznych badań ideologii liberalizmu Mykoły Konrada*
}

\begin{abstract}
Mykola Konrad (1876-1941) was an Ukrainian Greek Catholic priest, Doctor of Theology and Philosophy, Ukrainian historian of philosophy. The written heritage of the thinker, in addition to study on the history of philosophy, consists of works devoted to ideologies, in particular, liberalism, his vision of which Konrad outlined in his work Main Directions of Contemporary Sociology. Part 1. Liberalism (Lviv: Ed. "Bohosloviia”, Part 21, 1936). In order to study Father Conrad's vision of liberalism in the relevant religious and philosophical context, it was necessary to find out why the thinker reviewed this tradition of political thought in the context of sociology. It was important to compare Conrad's views with those of well-known Catholic thinkers. As a result of the study, it was established that the determination and vision of the sociology development by M. Konrad and European neo-Thomist philosophers A. Ushenichnik, A. Roshkovskyi, A. Shimanskyi, V. Cathrein, Y. Biderlyak is similar. Its sources are the social and ethical teachings of the Catholic Church, built on the principles of Neo-Thomism. They identified the subject and objectives of Catholic sociology, aimed at solving social issues, which formed the need
\end{abstract}

Dziękuję serdecznie mojej rodzinie i wszystkim, którzy pomogli mi w znalezieniu bibliografii i opublikowaniu artykułu. 
to study ideologies. Consequently, Father M. Conrad's consideration of liberalism within the framework of sociology was quite correct. The next task is to investigate what the Ukrainian thinker's understanding of liberalism was and what influence the sociological context had on him.

Keywords: history of philosophy, history of sociology, Catholic sociology, neoThomism

\section{Wstęp}

Dziedzictwo naukowe Mykoły Konrada (1876-1941), duchownego greckokatolickiego, doktora teologii i filozofii, ukraińskiego historyka filozofii, dziekana Wydziału Filozofii Ukraińskiej Greckokatolickiej Akademii Teologicznej we Lwowie (dalej: LBA), od dawna wzbudza zainteresowanie ukraińskich badaczy ${ }^{1}$, jednak wymaga jeszcze szczegółowych i obiektywnych badań. Pisemne dziedzictwo myśliciela, oprócz dzieł dotyczących historii filozofii, stanowią prace poświęcone ideologiom, w szczególności liberalizmowi.

Rezultatem badań historyczno-filozoficznych ideologii liberalizmu prowadzonych przez ukraińskiego filozofa była praca Główne kierunki najnowszej socjologii. Część pierwsza. Liberalizm². Impulsem do jej napisania był kurs socjologii, który wraz z kursami filozofii starożytnej i najnowszej Konrad prowadził na zaproszenie metropolity Andrzeja Szeptyckiego od 1929 do 1939 roku w LBA.

W celu zbadania poglądów ojca Konrada na liberalizm w odpowiednim kontekście religijno-filozoficznym konieczne jest ustalenie, dlaczego myśliciel rozważał tę tradycję myśli politycznej w odniesieniu do socjologii. Aby to zrobić, należy się dowiedzieć, jakie było ówczesne rozumienie nauki

1 Y. Zawchorodniy, W. Sawran, B. Gołowyn, o. M. Szawaryn itd. Więcej, a także o biografii intelektualnej M. Konrada można przeczytać w: Oksana Szeremeta, „Ojciec Mykoła Conrad: recenzje jako źródło rekonstrukcji historyczno-filozoficznych poglądów myśliciela”, Studia z Historii Filozofii 3 (2018): 191-208.

2 Dr. Mykola Konrad, Osnovni napryamky novitn'oyi sotsiol'ogiyi. Persha chast'. Liberalizm (L'viv: Vydannya «Bohosloviyi», Ch. 21, 1936). 
o społeczeństwie oraz na podstawie jakich źródeł i kierunków filozoficznych powstało ${ }^{3}$. Chodzi o socjologię katolicką. Historia rozwoju tej dyscypliny jest szczególnie interesująca.

\section{Źródła socjologii katolickiej}

Głównym źródłem ukształtowania się socjologii katolickiej jako odrębnej dyscypliny była nauka społeczna Kościoła katolickiego. Istotnym bodźcem do jej rozwoju było narastanie kryzysowych zjawisk społeczno-gospodarczych i politycznych w XIX i pierwszej połowie XX wieku. Fundamentalne znaczenie dla tego procesu miała, napisana z pozycji neotomizmu i wydana przez Leona XIII w 1891 roku, encyklika Rerum novarum. Zainicjowała ona rozwój nowoczesnej nauki społecznej Kościoła katolickiego. Nauka ta miała jednak znacznie starsze pochodzenie. Z czasem, w średniowieczu, nauka społeczna stała się częścią teologii i filozofii religijnej. Później, w ramach neotomizmu Leona XIII i jego zwolenników, wyróżniła się jako odrębna nauka4.

$\mathrm{Na}$ ten temat Antoni Szymański napisał, że katolicka nauka społeczna wywodzi się z Objawienia Bożego, które zawarte jest w księgach Starego i Nowego Testamentu. Zdaniem filozofa na podstawie tekstów biblijnych

3 W kontekście problemu ważne jest zbadanie, jaka była wizja socjologii w pracach znanych filozofów, naukowców, wykładowców katolickich, których idee były znane Konradowi: do ich dzieł wielokrotnie odwoływał się w Głównych kierunkach najnowszej socjologii. Część pierwsza. Liberalizm. Są to m.in.: Leopold Caro (1864-1939) - polski ekonomista, solidarysta, badacz migracji; Wiktor Cathrein (Victor Cathrein; 1845-1931) - szwajcarsko-niemiecki filozof, jezuita i neotomista, który oprócz moralności badał problemy społeczne, prawa, ekonomii, pokoju, równości; Józef Biderlyak (Joseph Biderlyak; 1845-1930) - profesor Uniwersytetu w Innsbrucku, Katolickiej Szkoły Wyższej w Austrii, autor wielu prac naukowych, w tym poświęconych zagadnieniom teologii i socjologii, wydanych w wielu językach, w tym w języku ukraińskim; Aleś Uszenicznik (slv. Aleš Ušeničnik; 1868-1952) - duchowny rzymskokatolicki, jeden ze znanych filozofów neotomistów Słowenii, socjolog, profesor teologii Uniwersytetu w Lublanie; Antoni Roszkowski (1894-1939) - docent Uniwersytetu Poznańskiego, profesor seminarium w Łodzi; Antoni Szymański (1881-1942) - rektor Katolickiego Uniwersytetu Lubelskiego, założyciel szkoły katolickiego nauczania społecznego.

4 Oksana Sheremeta, Etychni ideyi mytropolyta Andreya Sheptyts'koho u relihiynofilosofs'komu konteksti kintsya XIX-pershoyi polovyny XX st. (Kyyiv: [b.w.], 2010), 54. 
rozwinęła się autentyczna nauka - nauka apostołów, synodów kościelnych (które w przeszłości zajmowały się wieloma kwestiami gospodarczymi i społecznymi - lichwa, niewolnictwo, godziwa płaca), papieży, biskupów itp., która została odzwierciedlona w licznych dokumentach Kościoła katolickiego ${ }^{5}$. Szymański szczególnie wyróżnił encykliki: Vix pervenit (1745) olichwie BenedyktaXIV, Quantacura iSyllabus errorum (1864) o ówczesnych istotnych błędach Piusa IX (potępiał niektóre nurty filozoficzne i ideologie, m.in. liberalizm), Immortale Dei (1885) o chrześcijańskim ustroju państwa, Libertas (1888) o ludzkiej wolności i wiele innych Leona XIII i jego następców ${ }^{6}$.

Autor wyróżniał wśród źródeł katolickiej socjologii przeszłości doktrynalną naukę Kościoła, do której zaliczył pisma teologów, filozofów i socjologów katolickich (od czasów patrystyki i scholastyki, w których wybitna była według niego doktryna św. Tomasza z Akwinu, do współczesności), oraz doktrynę naturalnego prawa moralnego w sprawach społecznych i ekonomicznych ${ }^{7}$.

Bezpośrednim powodem napisania encykliki Rerum novarum była „kwestia robotnicza”. Analiza sytuacji robotników najemnych, którzy byli społecznie niepewni i podlegali wpływom idei socjalistycznych, wiązała się z szerszym kontekstem rozwoju nauki społecznej Kościoła. To zadanie było ważne pod wieloma względami, w tym dla rozwoju socjologii katolickiej.

5 Według obserwacji A. Szymańskiego współczesna działalność Stolicy Apostolskiej nabiera charakteru pozytywnego w przeciwieństwie do negatywnego - ostrzegawczego. Przekazuje ona deklaracje, wskazówki zachęcające do działania i kierujące wysiłkami katolików na rzecz poprawy życia w dobrym kierunku (X. Antoni Szymański, Zagadnienie społeczne (Lublin: Towarzystwo Wiedzy Chrześcijańskiej, 1938), 3). Oczywiście w szczególny sposób dotyczy to poprawy sytuacji materialnej pracowników, zabezpieczenia społecznego ich i ich rodzin, sprawiedliwego wynagrodzenia, zatrudniania kobiet i dzieci, czyli szeregu kwestii związanych z etyką, ekonomią i prawem. Dlatego katoliccy filozofowie-socjologowie rozważają obok zagadnień etycznych i prawnych także ekonomiczne. Niekiedy zdobywali oni wykształcenie ekonomiczne i poświęcali osobne badania ekonomii, jak w przypadku A. Roszkowskiego, który jest znanym polskim ekonomistą, autorem prac z zakresu ekonomii i katolickiej nauki społecznej, w szczególności: Katolicyzm społeczny - Zarys rozwoju poglądów społeczno-katolickich (Poznań: Księgarnia św. Wojciecha, 1932), Korporacjonizm katolicki (Poznań: Księgarnia św. Wojciecha, 1932).

${ }^{6}$ Szymański, Zagadnienie społeczne, 2-3.

7 Tamże, 5-6. 
Obdarzona własnymi zasadami teologicznymi i antropologicznymi nauka społeczna miała ujawniać normy prawa naturalnego i nadprzyrodzonego, które powinny być stosowane w sferze społecznej, w tym - zasady solidarności, wzajemnej pomocy, poszanowania dobra wspólnego. Stała się specyficzną etyką społeczną zachowań osobistych i zbiorowych w społeczeństwie. Encyklika miała również wyjątkowe znaczenie dla kształtowania etyki neotomistycznej ${ }^{8}$.

W czterdziestą rocznicę publikacji Rerum novarum Pius XI wydał encyklikę Quadragesimo anno (1931), która stała się jednym z najwybitniejszych dokumentów rozwijających naukę społeczną Kościoła katolickiego. Podkreślano w niej, że decydujące dla życia społecznego powinno być dobro wspólne. Jednostki w społeczeństwie powinny mieć taką samą wolność i odpowiedzialność. W stosunkach społecznych powinien panować solidaryzm. Szczególnym rodzajem solidarności może być dobrowolna subsydiarność zaangażowanie bogatych $\mathrm{w}$ pomoc biednym. Zasady solidarności i subsydiarności Pius XI przeciwstawił marksistowskiej zasadzie walki klasowej.

Katolicka nauka społeczna i zrozumienie potrzeby badania złożonych procesów istnienia i rozwoju społeczeństwa skłoniły myślicieli katolickich do kształtowania własnych wizji socjologii jako nauki, często w opozycji do idei pozytywistycznych. Kwestia robotnicza, która ich zdaniem była ściśle związana z ideologiami leżącymi u podstaw ekonomii i polityki, stała się ważnym powodem pojawienia się socjologii katolickiej (uwzględnienie w niej liberalizmu wydaje się więc całkiem słuszne). Była uważana za główny problem społeczny tamtych czasów i stała się synonimem nauki o społeczeństwie. Jednak wizja katolickich myślicieli socjologii chrześcijańskiej kształtowała się stopniowo i miała różne tło filozoficzne.

8 Sheremeta, Etychni ideyi mytropolyta Andreya Sheptyts'koho u relihiyno-filosofs'komu konteksti kintsya XIX-pershoyi polovyny XX st., 54-55.

9 Tamże, 58. 


\section{Tło filozoficzne socjologii katolickiej}

Jednym z przykładów wizji historii socjologii jest opinia Leopolda Caro, autora pracy Socyologia, t. 1: Wstęp do socyologii. Cz. 1 (Lwów, 1912). Caro dzielił socjologię na świecką i chrześcijańską. Początki socjologii świeckiej wyprowadzał z XVI wieku ${ }^{10}$, a rozwój socjologii chrześcijańskiej - z wieku XVII. Filozoficznym tłem tej ostatniej był augustynizm. Zdaniem Caro myśl św. Augustyna o dwóch kategoriach narodów i ludzi - dzieciach Bożych i dzieciach świata, o ich nieustannej walce i ostatecznym zwycięstwie Kościoła, wypowiedzianą w dziele Państwo Boże (413-427), konsekwentnie rozwijało w swoich dziełach wielu myślicieli ${ }^{11}$.

Filozoficzną podstawą socjologii religijnej u Caro była nauka św. Augustyna. Jednak odkąd w Kościele katolickim został przedstawiony program odrodzenia tomizmu, dla większości katolickich filozofów religijnych stała się nią nauka św. Tomasza z Akwinu. Uważano, że neotomizm może i powinien być podstawą kompleksowej syntezy filozoficznej, systemu filozoficzno-teologicznego, który składałby się ze wszystkich dyscyplin filozoficznych

10 Za pierwszego, jego zdaniem, europejskiego socjologa należy uznać francuskiego prawnika i filozofa Jeana Bodina (1529-1596). Następnie Vico, Monteskiusza, Rousseau, Voltaire’a, Kanta i innych (Leopold Caro, Socyologia, t. 1: Wstęp do socyologii. Cz. 1 (Lwów: nakładem autora, skład główny w księgarni H. Altenberga, 1912), 31). Pisząc o A. Comcie, Caro zauważa, że jest on twórcą najnowszej nauki o społeczeństwie i jej nazwy. Tamże, 34. Wyjaśniwszy jego poglądy, przechodzi do charakterystyki szkół w socjologii.

11 Według Caro jako pierwszy myśl św. Augustyna, przedstawioną w opracowaniu Państwo Boże, w swojej pracy Refleksje nad historia powszechna (fr. Discours sur l'Histoire universelle, 1681), rozwijał Jakób Benigna Bossuet (fr. Jacques-Bénigne Bossuet; 1627-1704) francuski duchowny katolicki, biskup, teolog, pedagog i kaznodzieja na dworze Ludwika XIV, a także wpływowy myśliciel polityczny. Później kontynuowali: Bonald (fr. Louis Gabriel Ambroise de Bonald; 1754-1840) - francuski filozof, przedstawiciel konserwatyzmu w myśli politycznej XIX wieku; de Maistre (fr. Joseph-Marie Comte de Maistre; 1753-1821) - filozof katolicki, literat, polityk i dyplomata, przedstawiciel fundamentalnego konserwatyzmu; Görres (niem. Johann Joseph von Görres; 1776-1848) - niemiecki myśliciel katolicki, teolog; Schlegel (niem. Friedrich Schlegel; 1772-1829) - niemiecki filozof, krytyk, językoznawca. Caro pisał, że należy tu wspomnieć także Fichtego, który w duchu św. Augustyna walczył z Schellingiem. Tamże, 33. 
i teologicznych ${ }^{12}$. Socjologia nie była wyjątkiem. Myśliciele katoliccy, zwłaszcza duchowni, rozwijali ją na zasadach neotomizmu.

W tym kierunku rozwój socjologii widział Aleś Uszenicznik, o czym pisał w swoim dziele Podstawy socjologii ${ }^{13}$. Myśliciel przede wszystkim poszukiwał podstawy każdego ludzkiego działania, w tym nauki o społeczeństwie. Dla niego tą podstawą była philosophia perennis, ponadczasowa filozofia, metafizyka doświadczana $w$ walce przez dwa tysiące lat. Została ona, choć nie bez błędów, systematycznie opracowana przez Arystotelesa, na nowo zinterpretowana przez św. Tomasza z Akwinu, dzięki nowoczesnej nauce potwierdzona przez belgijskiego kardynała Désiré-Josepha Merciera ${ }^{14}$.

Uszenicznik uważał pozytywizm za kierunek bez odpowiedniej podstawy, ponieważ został pomyślany jako areligijny, oparty na jasnych dowodach empirycznych. W konsekwencji zbudowana na jego gruncie socjologia nie miała odpowiednich fundamentów. Stąd jego zdaniem pojawiła się potrzeba mówienia o socjologii chrześcijańskiej, zbudowanej na zasadach wiary chrześcijańskiej, prawdziwej podstawie każdej działalności człowieka, która powinna być dostosowana do potrzeb społeczeństwa, a nie tylko suchej teorii ${ }^{15}$.

Przyczyną skojarzeń podejścia pozytywistycznego z suchym teoretyzowaniem było wyolbrzymianie znaczenia danych eksperymentalnych. Za jedną z jego konsekwencji Uszenicznik uznawał prawdopodobieństwo rozwoju nauki tylko dla nauki. Filozof uważał więc, że należy odrzucać pozytywizm opierający się jedynie na faktach ${ }^{16}$.

Myśliciel w żadnym wypadku nie umniejszał potrzeby stosowania precyzyjnych technik w nauce ani nie zaprzeczał jej, rozumiał znaczenie przeprowadzania eksperymentów. Jednocześnie uważał, że empiryczność nauki nie jest powodem odejścia od religii. Uszenicznik pisał, że chrześcijaństwo ma w sobie siłę, by zmienić świat na lepsze i stworzyć raj na ziemi, jeśli ludzkość tego zechce, ale samej metafizyki do tego nie wystarczy. Katechizm uczy,

12 Sheremeta, Etychni ideyi mytropolyta Andreya Sheptyts'koho u relihiyno-filosofs'komu konteksti kintsya XIX-pershoyi polovyny XX st., 49.

${ }_{13}$ Dr. Alesh Ushenichnik, Osnovy sotsiol'ogiyi, ukr. pereklad o. M. Firaka (L'viv: Biblioteka Ukrayins'koyi Khrystiyans'koyi Organizatsiyi, Ch. 1, 1927).

14 Tamże, 22.

15 Tamże, 33.

16 Tamże, 21. 
co jest dobre, a co złe, co należy czynić i czego unikać, prowadzi człowieka w dobrym kierunku. Nie daje jednak odpowiedzi na wszystkie pytania. Nie pisze, jak lepiej zorganizować działalność, aby osiągnąć niezbędne korzyści materialne, o ekstensywnym lub intensywnym gospodarstwie, o tym, jakie nasiona najlepiej rodzą na danym rodzaju gleby i tak dalej ${ }^{17}$.

Przeciwstawienie religii i nauki, jak również wiedzy humanistycznej i stosowanej, nie zostało zaakceptowane przez filozofa. Był zwolennikiem odpowiedniej do potrzeb i sytuacji współpracy między nimi. Dla Uszenicznika fundamentalnie ważne było to, aby podstawy nauk opierały się na zasadach chrześcijańskich. Takie podejście, jego zdaniem, podniosło ich znaczenie jako koniecznej i nieodłącznej działalności, która ma swoje miejsce w życiu człowieka obok katechizmu i etyki.

\section{Etyka - ważny element socjologii katolickiej}

Uszenicznik uznawał za ważny element socjologii chrześcijańskiej, który określa, co jest moralne, a co nie, etykę chrześcijańską - naukę o źródle i kierunku moralności ${ }^{18}$. Kwestia niezbędości etyki dla socjologii, ekonomii i innych nauk wywołała dyskusje wśród naukowców z badanego okresu. Zgodnie z katolicką nauką społeczną katoliccy filozofowie neotomiści uważali, że moralność jest ważna dla każdej ludzkiej działalności, w tym naukowej. Etyka stała się zatem w ich poglądach integralnym elementem socjologii katolickiej, co potwierdził w swojej pracy Uszenicznik.

\section{Socjologia - katolicka nauka teoretyczna czy praktyczna?}

Słoweński neotomista rozumiał socjologię nie jako teoretyczną naukę empiryczną, dowodzącą istnienia pewnych faktów, lecz znacznie szerzej. Według

\footnotetext{
17 Tamże, 34.

18 Tamże, 25.
} 
niego socjologia powinna obejmować wszystkie kierunki życia i działalności społeczeństwa, przede wszystkim etykę, a także politykę, w tym ideologię i ekonomię, oraz powinna opierać się na metafizycznych zasadach i nauce św. Tomasza z Akwinu. Jako nauka praktyczna powinna nie tylko stwierdzić istnienie problemów w społeczeństwie, ale również wskazać sposoby ich rozwiązania $^{19}$.

Podobnie rozumiał socjologię neotomista Antoni Roszkowski. Pisał, że według św. Tomasza $\mathrm{z}$ Akwinu naukami w sensie ścisłym są nauki spekulacyjne. Natomiast nauki przyrodnicze i historyczne nie są naukami w pełnym tego słowa znaczeniu. Św. Tomasz z Akwinu przyjął podział filozofii Arystotelesa na teoretyczną i praktyczną, a nauki społeczne zaliczył do nauk praktycznych ${ }^{20}$. W związku z tym Roszkowski rozumiał socjologię jako naukę praktyczną.

Dyskusja na temat tego, jaka powinna być socjologia - teoretyczna czy praktyczna, skierowała rozwój koncepcji katolickich myślicieli religijnych w nurt filozofii społecznej, w ramach której dziś prowadzone są również badania nad ideologiami. Dowodzi tego Stanisław Krajski, badacz poglądów na filozofię polityczną polskich myślicieli katolickich okresu międzywojennego, który zauważa, że pracowali oni nad zasadami doktryny społecznej, nazywanej „myślą społeczną”, „katolicką myślą społeczną”, „socjologią”. Jednak w ramach swojej społecznej refleksji nad socjologią i naukami ekonomicznymi zwrócili się ku filozofii społecznej. Krajski, analizując poglądy Roszkowskiego, wskazuje, że według myśliciela socjologia jest nauką, która zajmuje się badaniem społeczeństw takimi, jakimi były lub są, z ich instytucjami, prawami, zwyczajami, okolicznościami życia, lub nauką o społeczeństwach, które są jednocześnie rozważane w kontekście ich organizacji, funkcjonowania i rozwoju. Taka definicja socjologii jest możliwa tylko wtedy, gdy uznaje się, że nie ma ona żadnych podstaw światopoglądowych. Jednak w opinii myślicieli katolickich okresu międzywojennego takie podstawy są zawsze obecne. Jeśli pochodzą ze światopoglądu teistycznego, czyli filozofii katolickiej i teologii, to mamy do czynienia z socjologią katolicką czy - jak pisał Roszkowski - z katolicką koncepcją socjologiczną. Stąd jej zadaniem jest nie

\footnotetext{
19 Tamże, 9.

20 Roszkowski, Korporacjonizm katolicki, 55.
} 
tylko stwierdzenie tego, co jest, ale także ocena rzeczywistości i wskazanie, co powinno być. Szymański, biorąc pod uwagę pole badań zarysowane przez Roszkowskiego, twierdził, że odnosi się ono do teoretycznej socjologii empirycznej i filozofii społecznej. Teoretyczna socjologia empiryczna zdaniem Szymańskiego pozbawiona jest jakichkolwiek podstaw światopoglądowych, gdyż bada prawa powstania, istnienia, rozwoju i upadku grup społecznych, a właściwie powiązania między jednostką a grupą oraz między grupami, przebieg procesów społecznych (o taką właśnie socjologię, jak zostanie to pokazane dalej, chodziło Leopoldowi Caro - O. S.). Filozofia społeczna, powołując się na podstawy filozoficzne, rozważa kwestię źródeł życia społecznego, źródeł uprawnień organów władzy publicznej, norm porządku publicznego, powiązań między jednostką a grupą społeczną. Szymański ustalił treść takich pojęć, które są moralne i określają to, co powinno być. Pisał też, że socjologia bada zjawiska ekonomiczne, zwłaszcza społeczno-ekonomiczne, w świetle oceny moralnej.

Zdaniem Krajskiego, kiedy Szymański pisze o teoretycznej socjologii empirycznej, sugeruje to, że Roszkowski mówi o socjologii teoretycznej. A to, co Roszkowski nazywa socjologią praktyczną, Szymański określa jako filozofię społeczną. Podsumowując, Krajski zauważa, że polscy myśliciele katoliccy podejmowali refleksję na temat natury społeczeństwa i odwoływali się w jej granicach zarówno do wyników badań socjologii we współczesnym rozumieniu tego słowa, interpretowanej w duchu filozofii klasycznej, jak i do decyzji podejmowanych na gruncie filozofii społecznej, która nawiązuje do badań socjologicznych ${ }^{21}$.

Myśliciele katoliccy nie byli jednomyślni w pytaniach o filozoficzne podstawy socjologii katolickiej i jej historię. Caro stwierdzał jej obecność w twórczości św. Augustyna, śledząc jego poglądy w pracach filozofów aż do Fichtego. Uszenicznik z pozycji neotomistycznych argumentował potrzebę rozwoju socjologii chrześcijańskiej (praktycznej) w opozycji do pozytywistycznej (teoretycznej). Jego wizja rozwoju tej nauki jest bardziej zbliżona do filozofii społecznej we współczesnym rozumieniu.

${ }^{21}$ Stanisław Krajski, Filozofia polityczna $w$ ujęciu polskich myślicieli katolickich $w$ latach 1918-1939 (Warszawa: Wydawnictwo Kardynała Stefana Wyszyńskiego, 2006), 106. 
Roszkowski wyróżniał socjologię teoretyczną (bez żadnych podstaw światopoglądowych; stwierdzał, co jest) i praktyczną (katolicką; wskazywał, co powinno być). Szymański zaś wyróżniał teoretyczną socjologię empiryczną (bez żadnych podstaw światopoglądowych i bliższą współczesnemu jej rozumieniu) i filozofię społeczną (katolicką; wskazując źródła życia społecznego i określając to, co powinno być). Katoliccy myśliciele neotomiści w swoich kursach mogli odwoływać się zarówno do wyników badań socjologii, jak i filozofii społecznej w dzisiejszym rozumieniu tego słowa, co znacznie rozszerzało przedmiot nauki. Ze względu na historyczny rozwój socjologii - i pozytywistycznej, i katolickiej - oraz stopniowe kształtowanie jej przedmiotu i pola badawczego słuszne wydawało się uwzględnienie w niej idei filozofii politycznej badanego okresu.

\section{Socjologia w ujęciu Mykoły Konrada}

Jak rozumiał socjologię i jej przedmiot Mykoła Konrad? Swoją wizję myśliciel kształtował zgodnie z nauką społeczną Kościoła katolickiego i encyklikami papieży, co jest jedną z cech wczesnego neotomizmu. Motywującym elementem jego badania jest cytat z encykliki papieża Piusa XI Caritate Christi compulsi (1932), która skupia się na trudnej sytuacji ówczesnego społeczeństwa, spowodowanej kryzysami społecznymi i gospodarczymi, bezrobociem, problemami materialnymi itp. Pojawienie się takich zjawisk ukształtowało potrzebę poznania ich istoty i przyczyn, a następnie poszukiwania sposobów ich rozwiązania. Konrad podkreślał, że jest to tzw. kwestia społeczna, którą zdaniem myśliciela zajmuje się socjologia ${ }^{22}$. Socjologia jest więc nauką, która bada istotę i przyczyny współczesnych kryzysów społecznych i gospodarczych i szuka sposobów ich rozwiązania.

Konrad wyjaśnił dalej, że socjologia zajmuje się poszukiwaniem odpowiedzi na pytanie, jak politycznie, ideologicznie, ekonomicznie zorganizować społeczeństwo, aby umożliwić sprawiedliwy podział tymczasowych dóbr, pojednanie między wszystkimi warstwami obywateli, aby ludzkość osiągnęła,

${ }^{22}$ Konrad, Osnovni napryamky novitn'oyi sotsiol'ogiyi. Persha chast'. Liberalizm, 3. 
w miarę możliwości, prawdziwy, ogólny i trwały dobrobyt ${ }^{23}$. Socjologia u Konrada wskazuje nie tylko na istnienie kwestii społecznej, ale także na potrzebę poszukiwania sposobów jej rozwiązania. Myśliciel nie tylko określał, jakie są problemy w społeczeństwie, ale również podkreślał, że socjologia musi wskazywać, jak społeczeństwo powinno się zmienić, aby osiągnąć ogólny dobrobyt. Konrad rozumiał więc socjologię jako naukę praktyczną.

W formułowaniu definicji socjologii Konrad odwoływał się do Wiktora Cathreina ${ }^{24}$. Nauka o społeczeństwie ze wszystkimi jego społecznościami, według Cathreina, jest ściśle związana z moralnością. Filozof pisał, że niektóre społeczności dla człowieka są wrodzone. Przede wszystkim jest to rodzina i państwo, można jeszcze dodać społeczeństwo ludzkie jako całość, wraz z istniejącymi państwami i stosunkami międzypaństwowymi, czyli prawem międzynarodowym ${ }^{25}$. W związku z tym moralność zawarta $\mathrm{w}$ ich podstawach jest ważna nie tylko dla ich istnienia i funkcjonowania, ale też dla kształtowania ludzkich osobowości, które z kolei będą budować nowe społeczności. Dlatego socjologia powinna zajmować się również kwestiami moralności. Myśl tę poparł także ukraiński filozof.

Konrad pisał, że w „nauce o kwestii społecznej” są trzy główne tematy: 1) „dolegliwości” społeczno-gospodarcze (kryzysy, pytania, problemy O. S.); 2) ustrój społeczno-gospodarczy; 3 ) normy działalności społeczno-gospodarczej, czyli prawo ${ }^{26}$. Filozof zauważył jednak, powołując się na Yosyfa Biderlyaka $^{27}$, że kwestia społeczna jest pytaniem nie tylko społeczno-ekonomicznym odnoszącym się do ekonomii społecznej, nie tylko prawnym,

23 Tamże.

${ }^{24}$ Konrad nawiązał do dzieła: Victor Cathrein, Philosophia moralis (Friburgi, Brisgoviae, Editio XIII, 1925). Można przypuszczać, że badania Cathreina były znane nie tylko kręgom naukowym i teologicznym, ale także prostemu ukraińskiemu czytelnikowi. Jego dzieło o. V. Katrayn, Vid ateyizmu do anarkhizmu, pereklav z 2-ho nimets'koho vydannya o. I. Plavyuk (L'viv: Nakladom Tovarystva s'v. Apostola Pavla. Z pechatni V. A. Shyykovs'koho, 1909) zostało wydane w języku ukraińskim przez jedno z towarzystw religijnych dla szerokiego grona czytelników.

25 S. J. Wiktor Cathrein, Filozofia moralna (filozofia moralności): Wykład naukowy porządku moralnego i prawnego, t. 4, cz. 2: Poszczególna filozofia moralności, przekł. wolny z wyd. niem. przez W. Gostomskiego (Warszawa: Księgarnia Gebethner \& Wolff, 1905), 8.

${ }^{26}$ Konrad, Osnovni napryamky novitn'oyi sotsiol'ogiyi. Persha chast'. Liberalizm, 3.

27 Yosyf Biderlyak, Suspil'ne pytannya: Prychynok do zrozuminnya yeho suty yeho rozvyazannya, pereklad z VII nim vydannya (L'viv, 1910), 3-9. 
związanym $\mathrm{z}$ ustrojem politycznym społeczeństwa, ale także $\mathrm{w}$ zasadzie filozoficznym, religijnym i moralnym ${ }^{28}$. Takie podejście do rozumienia socjologii Konrada, w ramach filozofii, z aspektami ekonomicznymi, prawno-politycznymi, religijno-moralnymi, było charakterystyczne dla ówczesnych katolickich myślicieli neotomistów. Jednocześnie przybliżał on naukę o społeczeństwie bardziej do filozofii społecznej niż socjologii we współczesnym ich rozumieniu.

Biderlyak w pracy Kwestia społeczna (Lwów, 1910) pisał, że z ekonomicznego punktu widzenia przyczyną kwestii społecznej jest podział społeczeństwa na klasę nadmiernie bogatych i klasę proletariuszy. Od strony społecznej jej pojawienie się było spowodowane nienaturalnym zaburzeniem stosunków społecznych. Źródłem kwestii społecznej są błędne poglądy na etykę, na genezę i istotę praw człowieka, na społeczną naturę człowieka, na pochodzenie i rolę państwa. Dlatego jest ona ściśle związana z religią, która jako wzór reprezentuje obiektywną moralność w przeciwieństwie do subiektywnej ${ }^{29}$. Filozof wyraźnie śledzi związek rozumienia socjologii z kwestią robotniczą, która jest rozważana $\mathrm{w}$ wymiarze ekonomicznym, politycznym i religijno-etycznym.

Podobnie do rozumienia socjologii podchodzi Aleś Uszenicznik. Pisząc o sporze między naukowcami, zwłaszcza uczestnikami Kongresu Polityków Społecznych w Wiedniu w 1909 roku, o to, czy socjologia powinna studiować tylko to, co jest, czy też to, co powinno być, Uszenicznik wyjaśnia, że rozumie socjologię $\mathrm{w}$ szerokim znaczeniu jako naukę o społeczeństwie i jego dobrobycie, która obejmuje również ekonomię społeczną. Uważał, że nie można wybierać między tymi dwoma stanowiskami, ponieważ teoria studiów społecznych powinna być poświęcona praktyce. Dlatego w naukach społecznych należy odrzucić pozytywizm oparty wyłącznie na faktach. Jego zdaniem nauki społeczne nie powinny rejestrować tylko tego, co było, co jest i co jest przewidywane. Powinny także wskazywać, jak powinno być, określić kierunek zdrowego rozwoju społecznego, dać ludzkości cenne pomysły na owocną pracę społeczną. W życiu społecznym nie decydują jedynie instynkty zbiorowe, ale w dużym stopniu idee. Czasami idee wywołują całe rewolucje,

28 Konrad, Osnovni napryamky novitn'oyi sotsiol'ogiyi. Persha chast'. Liberalizm, 3.

29 Biderlyak, Suspil'ne pytannya: Prychynok do zrozuminnya yeho suty yeho rozvyazannya, 3. 
ale nie takie, które wskazują na to, co jest, lecz takie, które głoszą, jak być powinno ${ }^{30}$. Wizja socjologii jako nauki praktycznej stworzona przez Uszenicznika jest zbliżona do wizji nakreślonej przez Conrada, Roszkowskiego i Szymańskiego oraz innych neotomistów. Rozważanie przez filozofa kwestii ekonomicznych wymagało studiowania zagadnień etycznych i politycznych. Tak szerokie rozumienie socjologii zakładało badanie ideologii i zbliżało je do filozofii społecznej.

Dla porównania Caro pisał, że jego zdaniem socjologia zajmuje się badaniem typowych zjawisk wzajemnego oddziaływania na siebie: ludzkich jednostek między sobą, co prowadzi do powstania związków; oddziaływania wszelkich związków na siebie (np. wpływ związków na ich uczestników - O. S.); tych związków na jednostki, a jednostek na dalsze związki; człowieka i natury w społeczeństwie, jednak tylko w takiej mierze, w jakiej wpływa to na istotę (np. wynalazek młota silnika parowego); badaniem instytucji i form, które każda $\mathrm{z}$ tych interakcji powołała do życia (np. własność prywatna, wiara religijna itp. $)^{31}$.

Aby wyjaśnić przedmiot socjologii, Caro porównuje ją z historią. W rozumieniu Caro socjologia interesuje się tylko zjawiskami typowymi, często powtarzającymi się, nie interesuje się zaś zjawiskami szczególnymi czy wyjątkowymi, jak np. historia. W przypadku tej ostatniej przedmiotem badań może być wiarygodny pojedynczy lub nawet wyjątkowy fakt $\mathrm{z}$ dowolnej dziedziny życia ludzkiego, czy to prawa, czy ekonomii ${ }^{32}$.

Wyjaśniając przedmiot socjologii, Caro pisał, że tę naukę interesują relacje między ludźmi zarówno dobrowolne, jak i przymusowe, zarówno zmienne, jak i stałe, związki publicznoprawne lub niezależne od woli człowieka (dziedziczna szlachta, kasty, rasy, lud, naród), tworzone na każdym etapie z inicjatywy człowieka (państwo, partie polityczne), i wreszcie - najpierwszy związek, powstały między mężczyzną i kobietą. Socjologia zajmuje się również związkami etycznymi, kulturowymi i gospodarczymi; bada tylko zjawiska społeczne, porządkuje, uogólnia, podkreślając w nich pewną jedność, a na podstawie uzyskanych wyników wyciąga odpowiednie wnioski.

\footnotetext{
30 Ushenichnik, Osnovy sotsiol'ogiyi, 9-10.

31 Caro, Socyologia, t. 1, 17-18.

32 Tamże, 18.
} 
Projektowanie przyszłości lub programu działania należy do etyki społecznej lub polityki. W ramach socjologii nie ma dla nich miejsca. Wszystko, co jest poza wytyczonymi przez Caro granicami, jego zdaniem należy do pokrewnych dziedzin, a nie do przedmiotu socjologii ${ }^{33}$.

Caro oddzielił także socjologię od filozofii, filozofii historii, biologii, psychologii i innych nauk. Odrębność socjologii według myśliciela nie leży w nowości jej przedmiotu, ponieważ jest on wspólny dla wielu nauk, ale w jego wizji. Szczególnym jego wymiarem jest istnienie powiązań i wzajemnego wpływu jednostek i grup społecznych ${ }^{34}$. Istotne znaczenie dla określenia i rozumienia socjologii mają więc według Caro powiązania i wzajemne relacje między jednostkami ludzkimi a grupami społecznymi. Socjologia oczywiście krzyżuje się z innymi naukami w pewnych momentach, jak np. $\mathrm{z}$ historią czy ekonomią ${ }^{35}$. Caro nie odchodzi całkowicie od przyjętej szerokiej wizji przedmiotu dyscypliny, pisze o naukach pomocniczych dla socjologii (historii, statystyce, ekonomii społecznej, biologii, psychologii indywidualnej i porównawczej, psychofizyce, antropologii przyrodniczej lub nauce o rasach, antropologii politycznej, która stosuje przyrodnicze zasady życia historycznego, etnografii opisowej jako nauce o niecywilizowanych narodach i etnologii porównawczej, która bada pojęcia, czyny, warunki istnienia ludów pierwotnych $)^{36}$.

Wizja socjologii nakreślona przez Caro jest bliższa jej współczesnemu rozumieniu. Myśliciel skupił się na badaniu faktów istnienia więzi w społeczeństwie, a nie na podstawach światopoglądowych z pozycji, z których jest owo badanie realizowane. Jednak Konrad nie odwołuje się do Caro w kwestii definicji socjologii i jej przedmiotu. Jest on zainteresowany nie tylko tym, co jest, ale także potrzebą sformułowania wskazania, co powinno być. Dla tego celu podstawy światopoglądowe są niezwykle ważne.

Jak już wspomniano, polscy myśliciele katoliccy - Szymański i Roszkowski - w ramach ówczesnego rozumienia socjologii zwracali się w pewnych kwestiach ku filozofii społecznej, która pozwalała lepiej rozwiązywać problemy praktyczne. Autorzy starali się maksymalnie objąć wszystkie obszary

\footnotetext{
33 Tamże, 20.

34 Tamże, 20-22.

35 Tamże, 22.

36 Tamże, 25-30.
} 
życia społecznego w celu jego harmonizacji zgodnie z normami etyki wyznania chrześcijańskiego.

Szymański pisał, że przez socjologię katolicką rozumie zagadnienia z życia ekonomicznego i społecznego społeczeństwa, zwłaszcza relacje między kapitałem a pracą, które są ściśle związane z zadaniami duszpasterskimi. Rozważał je w świetle ekonomicznej i społecznej nauki katolickiej. Właściwa praca duszpasterska i katolicka nauka społeczna wyznaczały granice kwestii społecznej u Szymańskiego ${ }^{37}$.

Myśliciel wyjaśnia, że katolicyzm, jako nauka religijna i moralna, obejmuje wszystkie obszary życia społeczeństwa, które dzieli na ekonomiczne i społeczne. Normy i prawa moralne w sferze ekonomicznej i społecznej reguluje katolicka etyka społeczna, która odgrywa ważną rolę w kwestii społecznej polskiego filozofa ${ }^{38}$.

Roszkowski uważał założenia światopoglądowe i etykę za integralną część socjologii katolickiej. Nie negował też pewnej zależności i związku ruchu społeczno-katolickiego z ideologiami (liberalizmu, socjalizmu), twierdził jednak, że ruch ten ma własną ideologię, która czasami może być nawet podobna w czymś do liberalizmu lub socjalizmu. Takie podobieństwa mogą pojawić się raczej na polu praktycznych postulatów, ale jej fundamentem są religijne i moralne podstawy katolicyzmu ${ }^{39}$.

\section{Zakończenie}

Według ojca Konrada socjologia jest tożsama z nauką o kwestii społecznej, która bada istotę i przyczyny powstawania współczesnych kryzysów społecznych i gospodarczych oraz poszukuje sposobów ich rozwiązania. Jej podstawą jest nauka społeczna Kościoła katolickiego i neotomizm. Z tych pozycji socjologia, jako nauka praktyczna, powinna wskazać, jakie powinno stać się społeczeństwo i w jaki sposób, aby osiągnąć dobro wspólne.

\footnotetext{
37 Szymański, Zagadnienie społeczne, 1.

38 Tamże, 2.

39 Roszkowski, Katolicyzm społeczny, 24-25.
} 
Porównanie poglądów Mykoły Konrada i znanych europejskich filozofów neotomistów - Alesia Uszenicznika, Antoniego Roszkowskiego, Antoniego Szymańskiego, Wiktora Cathreina, Yosyfa Biderlyaka - udowadnia, że mają oni podobną definicję i wizję rozwoju socjologii. Była ona rozwijana przez filozofów na zasadach neotomizmu, nauki społecznej i etycznej Kościoła katolickiego i obejmowała wiele zagadnień, m.in. moralność, ekonomię, politykę i prawo. Szerokie zrozumienie tematu, praktyczne ukierunkowanie nauki na rozwiązywanie wielu problemów społecznych, przede wszystkim kwestii robotniczej i konfliktów międzyklasowych, zmusiło filozofów do szukania rozwiązania w filozofii społecznej (czasami nawet definiowania socjologii katolickiej jako filozofii społecznej), a także w ekonomii, prawie, politologii itp. oraz studiowania ideologii popularnych w okresie międzywojennym. Właściwe źródło socjologii katolickiej - nauka społeczna i etyczna Kościoła katolickiego, rozbudowana na zasadach neotomizmu - określiło przedmiot i zadania dyscypliny mającej na celu rozwiązywanie problemów społecznych, które ukształtowały potrzebę studiowania ideologii. Dlatego rozpatrywanie liberalizmu przez Konrada w ramach socjologii było całkiem słuszne. Jednak kwestia rozumienia tej tradycji myśli politycznej przez myśliciela wciąż wymaga badań.

\section{Bibliografia}

Biderlyak Yosyf. 1910. Suspil'ne pytannya: Prychynok do zrozuminnya yeho suty yeho rozvyazannya, pereklad z VII nim vydannya. L'viv [b.w.].

Caro Leopold. 1912. Socyologia. T. 1: Wstęp do socyologii. Cz. 1. Lwów: nakładem autora. Skład główny w księgarni H. Altenberga.

Cathrein Wiktor S. J. 1905. Filozofia moralna (filozofia moralności): Wykład naukowy porzadku moralnego i prawnego. T. 4. Cz. 2: Poszczególna filozofia moralności, przekł. wolny z wyd. niem. przez Walerego Gostomskiego. Warszawa: Księgarnia Gebethner \& Wolff.

Konrad Mykola Dr. 1936. Osnovni napryamky novitn'oyi sotsiol'ogiyi. Persha chast'. Liberalizm. L'viv: Vydannya «Bohosloviyi», Ch. 21.

Krajski Stanisław. 2006. Filozofia polityczna w ujęciu polskich myślicieli katolickich w latach 1918-1939. Warszawa: Wydawnictwo Kardynała Stefana Wyszyńskiego. 
Roszkowski Antoni Ks. 1932. Katolicyzm społeczny: zarys rozwoju pogladów społeczno-katolickich. Poznań: Księgarnia św. Wojciecha.

Roszkowski Antoni Ks. 1932. Korporacjonizm katolicki. Poznań: Księgarnia św. Wojciecha.

Sheremeta Oksana. 2010. Etychni ideyi mytropolyta Andreya Sheptyts'koho u relihiynofilosofs'komu konteksti kintsya XIX-pershoyi polovyny XX st. Kyyiv [b.w.].

Sheremeta Oksana. 2018. „Ojciec Mykoła Conrad: recenzje jako źródło rekonstrukcji historyczno-filozoficznych poglądów myśliciela". Studia z Historii Filozofii 3: 191-208.

Szymański Antoni X. 1938. Zagadnienie społeczne. Lublin: Towarzystwo Wiedzy Chrześcijańskiej.

Ushenichnik Alesh Dr. 1927. Osnovy sotsiolohiyi, ukr. pereklad o. M. Firaka. L'viv: Biblioteka Ukrayins'koyi Khrystiyans'koyi Organizatsiyi, Ch. 1. 